\title{
Use of photovoltaic systems for rural electrification in Thailand
}

\author{
N. Rapapate ${ }^{1}$ and Ö. Göl ${ }^{2}$ \\ ${ }^{1}$ Ubon Ratchathani Rajabhat University \\ 2, Ratchathani Road, Muang, Ubon Rachathani 34000 \\ Thailand \\ ${ }^{2}$ University of South Australia \\ PO Box 2471, Adelaide SA 5001, Australia \\ Phone: +61 88302 3285, fax: +61 88302 3384, e-mail: Ozdemir.Gol@unisa.edu.au
}

\begin{abstract}
This paper addresses the need for electricity of remote rural communities in Thailand and proposes a minimalist photovoltaic solar home system scheme to supply electricity to non-electrified villages in isolated rural regions in Thailand. Details of the proposed SHS scheme are given. The estimated cost of the proposed scheme is compared with that of a grid extension. The paper reaches the conclusion that the proposal is justifiable on humanitarian, technical and economic grounds.
\end{abstract}

\section{Key words}

Photovoltaics, renewable energy, rural electrification, Thailand, solar home systems. remote communities.

\section{Introduction}

The use of photovoltaic (PV) solar home systems (SHS) can provide the much needed electricity in households in remote localities for such basic needs as lighting, TV and radio. This can significantly increase the quality of life for people in underdeveloped rural regions deprived of privileges that developed communities take for granted.

During the past few decades Thailand has successfully electrified up to $99 \%$ of rural Thai villages by connecting them to national distribution grids [1]. The remaining $1 \%$ is considered too far away and too difficult to electrify with grid extensions. A long grid extension is not cost-effective unless it is provided in an area with a high consumer density [2]. Grid connection seems to be out of question in rural villages where the consumer density is very low. Thus, the Provincial Electricity Authority (PEA), the country's dedicated rural electricity utility, is focusing on the use of stand-alone electricity generation, particularly solar PV systems for nonelectrified villages. Solar PV systems are considered as providing an acceptable alternative despite their relatively high initial cost.

\section{Some Facts about Thailand}

Thailand is located in the heart of Southeast Asia, occupying some $514,000 \mathrm{~km}^{2}$ [3] in the western half of the Indochinese Peninsula and the two-thirds of the northern Malay Peninsula. It is bordered by Burma (Myanmar) on the north and west, by Laos on the northeast, by Cambodia and the Gulf of Thailand on the southeast, by Malaysia on the south and by the Andaman
Sea on the southwest. The geographical shape of Thailand resembles an axe as can be seen in Fig. 1.

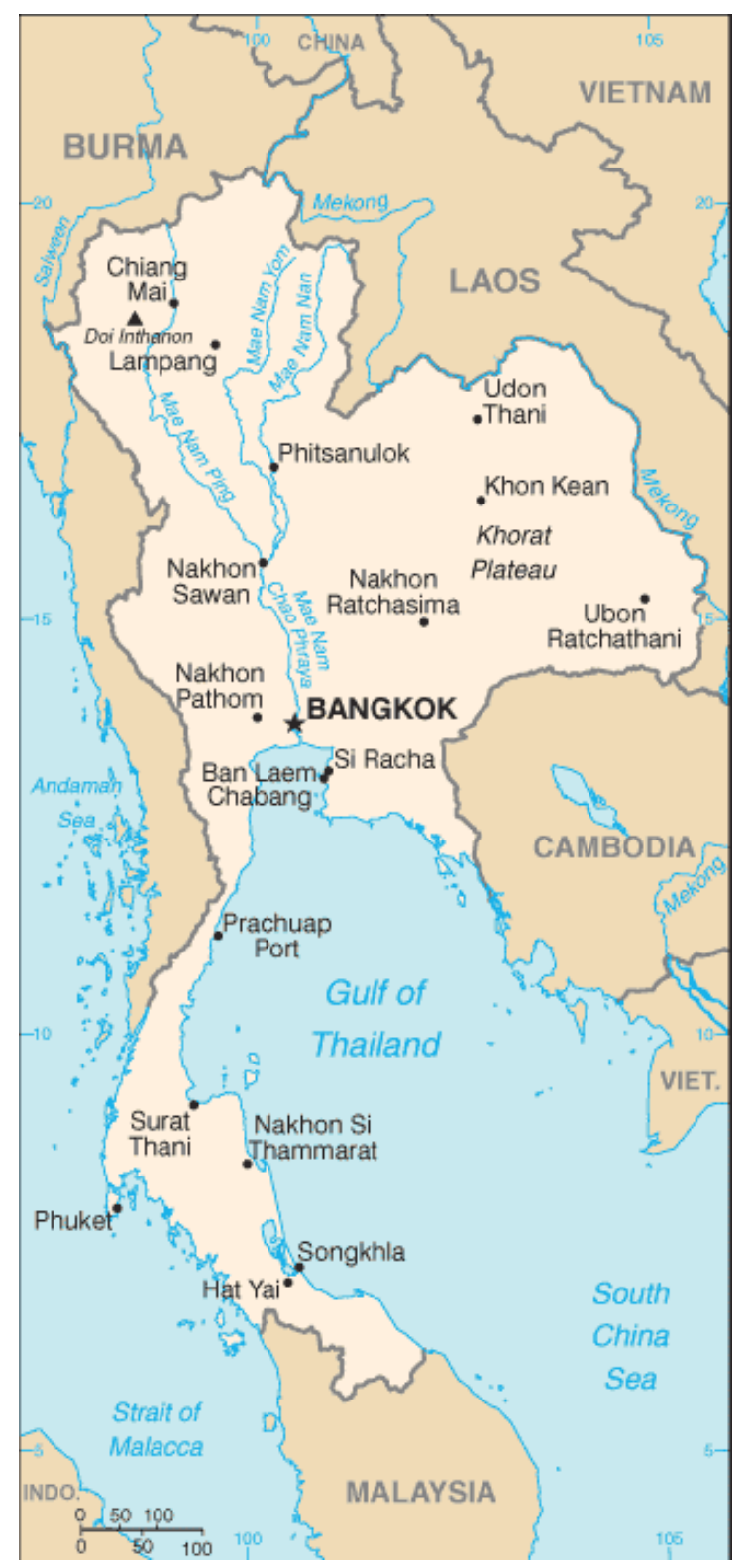

Fig. 1 Map of Thailand [3] 
Thailand is geographically divided into six major regions: the North, the Northeast, the Central, the East, the West and the South. The North is a mountainous region composed of ridges, natural forest and deep, narrow alluvial valleys mainly divided by four rivers: Ping, Wang, Yom and Nan, which merge in the lowlands to form the Chao Phraya River. In winter, the temperatures are cool enough for cultivation of fruits such as strawberries and peaches. The West, like the North, has a number of mountains and valleys. The Northeast is dominated by the saucer-shaped Korat Plateau, which extends into neighbouring Laos. Despite the presence of the great river Mekong at its eastern boundary, the region is barren, consisting mainly of dry and infertile soil and a few low hills. The short monsoon season brings heavy flooding in the river valleys. The Northeast has a long dry season and much of the land is covered by sparse grasses. Central Thailand is a fertile and lush area and possesses the richest and most extensive rice-producing regions in the country. Its principal and most famous river is Chao Phraya. Bangkok, the capital and largest city of Thailand, is situated on the southern edge of the region at the head of the Gulf of Thailand with Chao Phraya as its dominant geographic feature. The East is a coastal plain with fine sandy beaches and commercial ports for international trade such as Map Ta Phut. The South, a narrow peninsula, is hilly with thick forests and rich deposits of minerals and iron ore with spectacular beaches and islands along both shores.

\section{Rationale for use of PV in Thailand}

Thailand has a tropical climate with a high degree of humidity. There are three distinct seasons: hot, rainy and cool! The hot season is from March to May with high temperatures ranging from $30^{\circ} \mathrm{C}$ to $40^{\circ} \mathrm{C}$. During the rainy season, from June to October, the country experiences the southwest monsoons bringing billowing clouds and cool showers. The cool season, from November to February, is also called dry season affected by the northeast monsoons. The temperatures drop to a low of about $18^{\circ} \mathrm{C}$ and sometimes can be lower than $10^{\circ} \mathrm{C}$ in certain areas such as the mountains in the North and the Northeast. The Northeast experiences a long dry season.

Villages in rural Thailand usually consist of a small number of households, usually living in 5 to 10 houses with typically 4 to 5 people per household [4], [5]. They are located a considerable distance away from the grid, distance varying from $5 \mathrm{~km}$ to $40 \mathrm{~km}$ [4]. Moreover, many of the villages are difficult to access by transport, especially those in mountainous regions. This renders electrification by grid connection virtually impossible for a number of villages on both economic grounds and terrain. The Government's energy policy is cognisant of this and offers subsidies to cover virtually the full cost of SHS installation. The two government bureaus in charge of funding for the rural implementation of SHS are the Energy Policy and Planning Office (EPPO) and the Energy Conservation Fund (ENCON Fund) [4], [6], [7].
In gauging the feasibility of utilising solar energy for photovoltaic energy conversion at any global location, sunshine hours $(\mathrm{SSH})$ and peak sun hours $(\mathrm{PSH})$ assume particular importance. SSH simply denotes number of hours the sun shines at a given global location without any reference to the intensity of solar radiation. $\mathrm{PSH}$, on the other hand, designates the equivalent number of hours each day during which the insolation would average $1000 \mathrm{~W} / \mathrm{m}^{2}$. Thailand averages an impressive $P S H$ of 5 annually, the figure reaching 5.5 in the Northeast (Fig. 2) [8]. This is tantamount to having an average solar insolation of $5.5 \mathrm{kWh} / \mathrm{m}^{2}$, or some $20 \mathrm{MJ} / \mathrm{m}^{2}$, available for use daily. This has particular significance for the remote villages of the Northeast.



Fig. 2 The annual average daily solar irradiation in Thailand [4]

\section{A Minimalist Demand Analysis}

In rural Thai villages, power demand is small. People are mostly very poor. Their energy needs are by and large met by wood gathered from the surroundings for charcoal production and cooking. Kerosene wick lamps and candles are used for lighting at night. They need electricity for just the very basic essential needs. For example, they need modest artificial lighting to replace the kerosene lamp, TV and radio for news and information, and a fan for modest comfort in hot weather. They work as farmers: so they use electricity for just a few hours at night since they spend all day working on the land. Consequently, it seems not unreasonable to adopt a minimalist approach in quantifying the daily electricity demand of a typical village household in the northeast of Thailand (Table I). 
TABLE I. - Daily electricity demand for a typical rural household in the Northeast

\begin{tabular}{|l|c|c|c|c|c|}
\hline ITEM & $\begin{array}{c}\text { POWER } \\
(\mathrm{W})\end{array}$ & NO. & $\begin{array}{c}\text { TOTAL } \\
\text { POWER } \\
\text { (W) }\end{array}$ & $\begin{array}{c}\text { DAILY } \\
\text { USAGE } \\
(\mathrm{h})\end{array}$ & $\begin{array}{c}\text { DAILY } \\
\text { ENERGY } \\
\text { USED } \\
\text { (Wh) }\end{array}$ \\
\hline Lights & 18 & 3 & 54 & 3 & 162 \\
\hline Fan & 40 & 1 & 40 & 3 & 120 \\
\hline $\begin{array}{l}\text { Radio } \\
\text { cassette } \\
\text { player }\end{array}$ & 10 & 1 & 10 & 2 & 20 \\
\hline $\begin{array}{l}\text { Colour } \\
\text { TV }\end{array}$ & 80 & 1 & 80 & 3 & 240 \\
\hline Total & & & $\mathbf{1 8 4}$ & & $\mathbf{5 4 2}$ \\
\hline
\end{tabular}

\section{System Configuration}

Fig. 3 illustrates a stand-alone solar house system (SHS) proposed for adoption in the Northeast as an immediate interim measure toward satisfying the less than modest requirements of electricity of the inhabitants of remote rural communities. Fig. 4 shows the layout of a typical rural house.

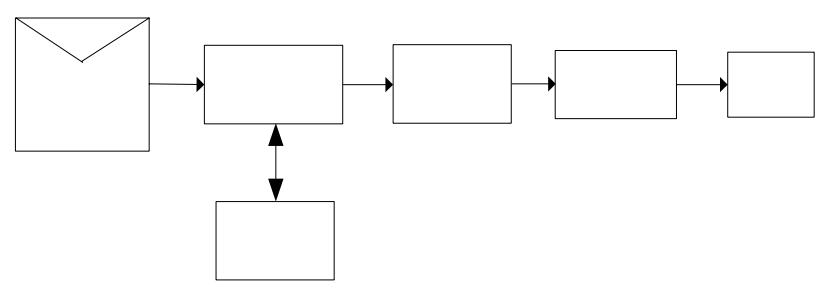

Fig. 3 Stand-alone SHS proposed for adoption
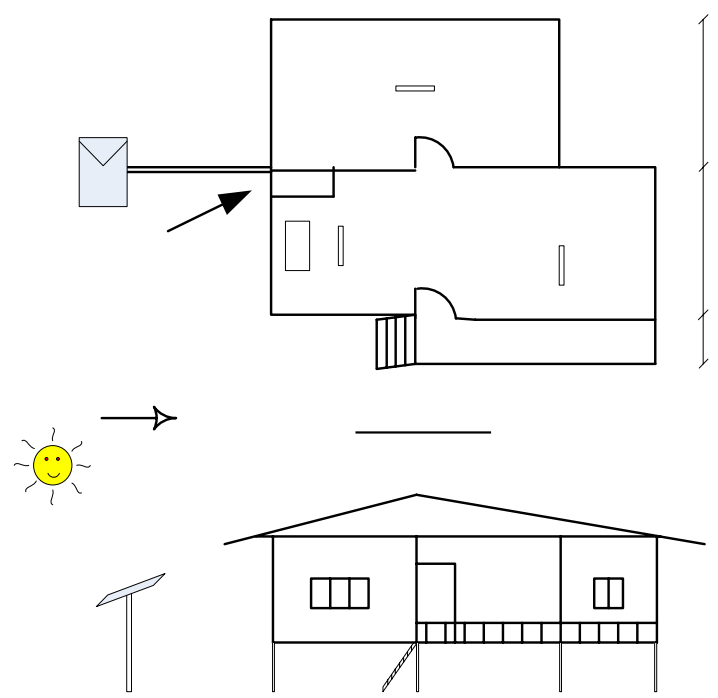

Fig. 4 A typical rural house layout with main SHS components
As indicated in Fig. 4 it is proposed to locate the controller, inverter and batteries in the living room inside the house. The cable run between the PV modules and controller can be laid underground or overhead. The latter is less expensive but requires greater care.

\section{A. Design considerations}

In designing the system a number of factors need to be taken into account. These include technical specifications, sizing of individual system components, safety considerations as well as system economics. The following is a condensed excerpt from the design process.

The proposed system comprises an inverter and batteries. Thus the efficiency of these system components, along with that of wiring, must be taken into account.

The gross daily energy demand for a typical remote household can be determined from

$$
E_{g d}=\frac{E_{n d}}{\eta_{i} \times \eta_{b} \times \eta_{w}}
$$

where $E_{g d}$ and $E_{n d}$ denote gross and net energy demand per day respectively. $\eta$ is efficiency with subscripts $i, b$ and $w$ referring to inverter, battery and wiring respectively.

Typical efficiencies are $85 \%$ for the inverter, $85 \%$ for batteries and about $98 \%$ for the system wiring in a welldesigned PV system [9]. With a net energy demand of $542 \mathrm{Wh}$ as per Table I, this yields a gross daily energy demand of just under 800 Wh per day.

\section{B. System Voltage}

It has been suggested that if the daily energy demand is more than $1 \mathrm{kWh}$, a system voltage of 24 Vdc should be considered, whereas $12 \mathrm{~V}$ is deemed to be a better choice if the daily energy demand is less than $1 \mathrm{kWh}$ [10]. On that basis, a system voltage of $12 \mathrm{~V}$ is adopted for design. With a daily energy demand of some $800 \mathrm{Wh}$, this translates into having to deliver about 70 Ah of daily charge capability (DCC).

\section{PV Modules}

In choosing the PV modules for implementation, several factors need to be considered including the daily demand, solar insolation at the geographic location as well as the method of mounting the modules.

It seems that the modest daily household energy demand of some 800 Wh can be easily met with the PSH of 5.5 of the Northeast. There are basically two options as far as mounting the PV cells is concerned: (a) fixed mounting, and (b) mounting on a tracker. The latter option may yield up to $20 \%$ more output but costs more and requires skilled maintenance. However, both in view of budgetary considerations and the villagers' lack of familiarity with 
the technology involved it is deemed best to opt for fixed mounting. Fig. 5 depicts a typical village house equipped with a SHS where the PV modules are mounted on a post in a fixed position.

The number of modules is derived on the basis of daily energy demand and the commercial availability of the module specified. In this case the total charge current is some $13 \mathrm{~A}$. From the various models available on the Thai market, it is proposed to use the type SC55 with the specification given in Table II, manufactured by Solartron Co., Ltd., a Thai company established in 1986 [11]. Four modules are to be used for the proposed SHS design.

TABLE II Solar Module Specifications [11]

\begin{tabular}{|l|l|}
\hline Rated Power, $\mathrm{W}$ & $55 \mathrm{~W}$ \\
\hline Configuration, $\mathrm{V}$ & $12 \mathrm{~V}$ \\
\hline Rated Current, $\mathrm{A}$ & $3.15 \mathrm{~A}$ \\
\hline Rated Voltage, $\mathrm{V}$ & $17.4 \mathrm{~V}$ \\
\hline Short Circuit Current $\left(\mathrm{I}_{\mathrm{sc}}\right), \mathrm{A}$ & $3.45 \mathrm{~A}$ \\
\hline Open Circuit Voltage $\left(\mathrm{V}_{\text {oc }}\right), \mathrm{V}$ & $21.7 \mathrm{~V}$ \\
\hline
\end{tabular}

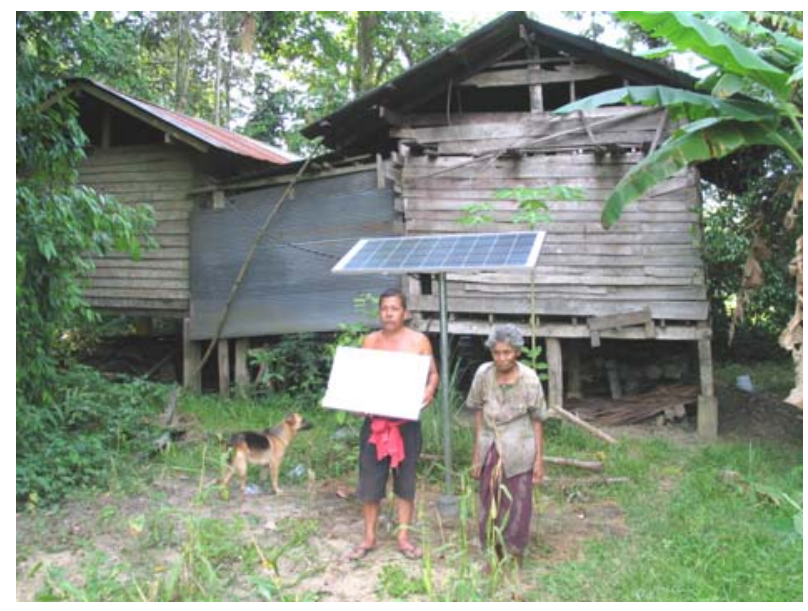

Fig. 5 Typical SHS implementation in Thailand with fixed mounting of PV modules

(Photograph: Courtesy Solartron Co., Ltd.)

\section{Charge Controller, Inverter and Batteries}

1) Charge controller. A charge controller is essential to the effective and safe operation of a SHS. The controller must be sized to handle maximum input currents produced by the PV modules and maximum output currents delivered to battery and load. Currents in the three main current circuits dictate the sizing of the charge controller [9]. They are the $i$ ) arrayto-controller current, ii) controller-to-load current, and iii) battery-to-controller current.

The array-to-controller circuit should be able to handle at least $125 \%$ of total short circuit current $\left(I_{s c}\right)$ [9]. This yields a maximum array-tocontroller current of $17.3 \mathrm{~A}$. The maximum controller-to-load current is obtained as $15.3 \mathrm{~A}$ from the total system power of $184 \mathrm{~W}$ and the system voltage of $12 \mathrm{~V}$. Of these two, whichever is the larger is to be chosen as the maximum battery-to-controller current. Allowance needs to be made to meet these current requirements. In the present case, a 20 A controller with a maximum 22 A input and output current will be chosen for the $12 \mathrm{~V}$ system. The controller proposed is the model SET- 1220 by Leo Electronics Co., Ltd. [12].

2) Inverter. The size of the inverter depends on the total load demand on the system. The inverter capacity $(I C)$ is obtained from:

$$
I C=\frac{P_{S H S}}{\eta_{i} \times \cos \varphi \times k_{\text {loss }}}
$$

where $P_{S H S}$ is the total estimated energy demand as determined before (Table I), $\eta_{i}$ is the inverter efficiency, $\cos \varphi$ is the power factor and $k_{\text {loss }}$ accounts for reduction due to of other system losses. Assuming 85\%, 0.9 and $85 \%$ for $\eta_{i}, \cos \varphi$ and $k_{\text {loss }}$ respectively, IC is determined as being 283W. Allowing for surge currents caused by the loads and market availability, a $600 \mathrm{~W}$ inverter is selected. The suggested unit for use is Apollo S-100 series stand alone inverter (Model S-102A) of Leo Electronics Co., Ltd. of Thailand [13].

3) Batteries. Battery specifications are to be derived from the daily energy demand, the number of days of storage required - the socalled days of autonomy (DOA) - and the maximum depth of discharge (DOD).

$D O A$ depends on where the system is to be located. In remote areas of Thailand blessed with abundant sunshine - as is the case in the Northeast - this may be safely taken to be 2 to 3 days per week. In the case presented, two storage days will be allowed for the system.

The maximum depth of discharge (DOD) refers to the lowest point to which the battery can be discharged before having to be recharged. For a deep discharge battery, $D O D$ can be as low as $40 \%$ state of charge [14]. However, in Thailand, a DOD of $60 \%$ is typically used for design specifications [4]. On this basis, the required battery storage capacity (BSC) is obtained from

$$
B S C=\frac{D C C \times D O A}{D O D}
$$

as being about 235 Ah. Thus, the storage requirements should be adequately met by two 125 Ah batteries connected in parallel. The battery proposed is BD125, manufactured by Leo Electronics Co., Ltd., of Bangkok, with the specifications shown in Table III [15]. 
TABLE III Battery Specifications [15]

\begin{tabular}{|l|l|}
\hline Model & BD125 \\
\hline Nominal Voltage & $12 \mathrm{~V}$ \\
\hline Nominal Capacity (at 5/20h) & $100 \mathrm{Ah} / 125 \mathrm{Ah}$ \\
\hline Configuration, V & $12 \mathrm{~V}$ \\
\hline Rated Current, A & $3.15 \mathrm{~A}$ \\
\hline Rated Voltage, V & $17.4 \mathrm{~V}$ \\
\hline Short Circuit Current $\left(I_{s c}\right), \mathrm{A}$ & $3.45 \mathrm{~A}$ \\
\hline Open Circuit Voltage $\left(V_{o c}\right), \mathrm{V}$ & $21.7 \mathrm{~V}$ \\
\hline
\end{tabular}

\section{E. Wiring and protection}

1) Wiring. Wiring design aims at determining the best possible layout and wire gauges for circuits by considering the currents carried by each circuit and ensuring that voltage drops are not significant [9]. A voltage drop of $\Delta \mathrm{V}=2 \%$ is considered most suitable for the best energy transfer although in practice $5 \%$ is also considered quite acceptable [9]. However, occasionally voltage drops of up to $10 \%$ voltage drops are tolerated in small power SHS schemes [14]

The proposed SHS has three major cable runs and four supply circuits as depicted in Fig. 6. Table IV gives further details, also listing the percentage voltage drop $\Delta \mathrm{V}$ for each circuit. With most voltage drop values being around the $2 \%$ mark, and none exceeding 5\% the wiring design can be considered to be acceptable.

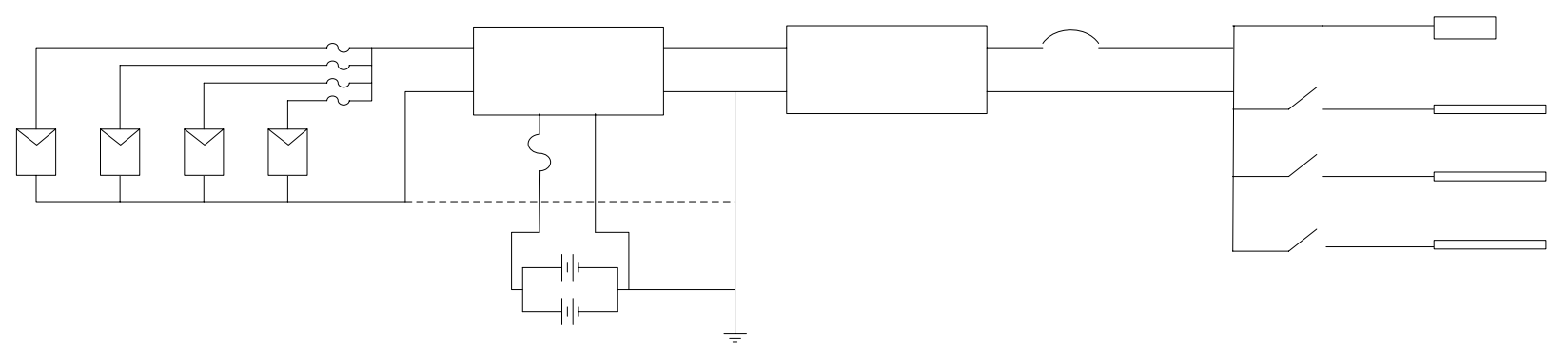

Fig. 6 Wiring diagram for SHS

Table IV - Voltage drops for the system

\begin{tabular}{|l|c|c|c|c|c|}
\hline CABLE RUN & $\begin{array}{c}\text { LENGTH } \\
(\mathrm{m})\end{array}$ & $\begin{array}{c}\text { CURRENT } \\
(\mathrm{max}) \\
(\mathrm{A})\end{array}$ & $\begin{array}{c}\text { SIZE } \\
\left(\mathrm{mm}^{2}\right)\end{array}$ & $\begin{array}{c}\mathrm{R} \\
(\mathrm{m} \Omega)\end{array}$ & $\begin{array}{c}\Delta \mathrm{V} \\
(\%)\end{array}$ \\
\hline $\begin{array}{l}\text { Module- } \\
\text { controller }\end{array}$ & 5 & 17.25 & 6 & 34 & 4.9 \\
\hline $\begin{array}{l}\text { Battery- } \\
\text { inverter }\end{array}$ & 2 & 15.33 & 4 & 20 & 2.6 \\
\hline $\begin{array}{l}\text { Controller- } \\
\text { battery }\end{array}$ & 1 & 17.25 & 4 & 10 & 1.4 \\
\hline Power point & 2 & 10.8 & 2.5 & 32 & 2.9 \\
\hline Bedroom & 5 & 1.5 & 1.5 & 135 & 1.7 \\
\hline $\begin{array}{l}\text { Living } \\
\text { room }\end{array}$ & 4 & 1.5 & 1.5 & 108 & 1.4 \\
\hline Kitchen & 7 & 1.5 & 1.5 & 189 & 2.4 \\
\hline
\end{tabular}

2) Protection. Fuses and a circuit breaker are used to provide protection for the PV modules, charge controller, inverter, batteries and appliances against system faults as shown in Fig. 6. Fuse sizes are usually determined on the basis of fault currents which exceed rated currents by $20-56 \%$. [7] [12]. For the design at hand, fuses are specified as listed in Table $\mathrm{V}$ for the major cable runs on the basis of fault currents likely to arise in the course of operation. A circuit breaker is employed between the inverter output and the load circuits.

Table V - Fuse sizing

\begin{tabular}{|l|l|l|}
\hline CIRCUITS & $\begin{array}{l}\text { Max } \\
\text { expected } \\
\text { current } \\
\text { (A) }\end{array}$ & $\begin{array}{l}\text { Fuse } \\
\text { size } \\
\text { (A) }\end{array}$ \\
\hline Module - controller & 3.45 & 6 \\
\hline Controller - batteries & 17.25 & 27 \\
\hline Inverter - loads & 15.3 & 24 \\
\hline
\end{tabular}

F. Cost considerations

1) Initial outlay. Table VI lists the prices of the SHS components that can be currently purchased on the Thai market and the total capital cost of the system. Purchase prices are given in Thai currency baht (THB).

Balance-of-system (BOS) in Table VI includes the cost of wiring, fuses, circuit breaker, array mount, ground rod and other miscellaneous expenses such as switches and outlets. The cost of $\mathrm{BOS}$ required is normally about $10 \%$ of the cost of the module [10]. In this case, the total 
purchase price of the modules is THB 44,000. Thus, BOS is estimated as being THB 4,400.

Table VI - Purchase prices and capital cost

\begin{tabular}{|l|r|c|r|}
\hline $\begin{array}{l}\text { SYSTEM } \\
\text { COMPONENTS }\end{array}$ & $\begin{array}{l}\text { UNIT } \\
\text { COST } \\
\text { (THB) }\end{array}$ & NO. & $\begin{array}{c}\text { TOTAL } \\
\text { COST } \\
\text { (THB) }\end{array}$ \\
\hline $\begin{array}{l}\text { PV module - 55 W } \\
\text { (SC55) }\end{array}$ & 11,000 & 4 & 44,000 \\
\hline $\begin{array}{l}\text { Battery - 125 Ah } \\
\text { (BD125) }\end{array}$ & 4,500 & 2 & 9,000 \\
\hline $\begin{array}{l}\text { Charge controller - } \\
\text { 20A 12V } \\
\text { (SE-1220) }\end{array}$ & 3,400 & 1 & 3,400 \\
\hline $\begin{array}{l}\text { Inverter - 600W } \\
\text { (S-102A) }\end{array}$ & 10,000 & 1 & 10,000 \\
\hline Circuit breaker & 700 & 1 & 700 \\
\hline BOS Total initial outlay & & $\mathbf{7 1 , 4 0 0}$ \\
\hline \multicolumn{2}{|c|}{} & & \\
\hline
\end{tabular}

2) Life cycle cost analysis. Life cycle cost (LCC) analysis constitutes an economics tool to aid in making investment decisions. The notions of present worth $(P W)$ and future worth $(F W)$ underpin the analysis. $P W$ is defined as the equivalent sum of money at today's value for money available at a point in time in the future [16]. $F W$, on the other hand, is described as the equivalent sum of money at a point in time in the future for money received or expended today [16].

Two factors affect the value of money over time: the inflation rate and the discount rate or rate of return. Inflation rate, $i$, is used to compute the decrease of money value in the future. Discount rate, $d$, or rate of return is a measure of the amount of interest that can be earned on the amount of money that has been invested or saved. Thus, $P W$ and $F W$ are obtained from

$$
\begin{gathered}
P W=\frac{F W}{(1+d)^{n}} \\
F W=P W \times(1+i)^{n}
\end{gathered}
$$

where:

$$
\begin{aligned}
& \mathrm{n}=\text { time period (years) } \\
& \mathrm{d}=\text { discount rate or rate of return (\% per annum) } \\
& \mathrm{i}=\text { inflation rate }(\% \text { per annum) }
\end{aligned}
$$

The life cycle cost ( $L C C$ ) can then be obtained by adding up the $P W$ of all expenditure, present and future. The $L C C$ may include capital expenditure, operating costs, component replacement costs as well as maintenance. Here the LCC analysis will be particularly useful since it allows the cost of grid connection to be compared with that of a SHS implementation [9]. In doing so, the future purchase prices of components that have to be replaced and their present values need to be calculated. Table VII presents the result for this case.

The minimum life expectancy of PV modules is 20 years. Thus the life of the system will be taken as 20 years. Inflation rate and discount rate are assumed to be $3 \%$ and $5 \%$ per annum respectively. Controller and inverter need to be replaced every 10 years. Batteries need replacement every two years. Consequently, during the 20-year life cycle of the system, controller and inverter need to be replaced once after 10 years of operation and batteries need to be replaced 9 times.

On the other hand, the current cost of grid connection in Thailand is approximately THB 650,000 per kilometre [6]. In general, villages in rural areas, which are not yet electrified, are at least $5 \mathrm{~km}$ - with some villages even further away from the grid. Hence, the minimum likely cost for grid connection is in the order of THB $3,250,000$, the cost reaching a whopping THB $26,000,000$ for a distance of $40 \mathrm{~km}$.

Table VII - LCC comparison between SHS and grid connection

\begin{tabular}{|l|l|r|r|r|}
\cline { 3 - 5 } \multicolumn{2}{l|}{} & Year & $\begin{array}{l}\text { Purchase } \\
\text { price } \\
\text { (THB) }\end{array}$ & $\begin{array}{l}\text { PW } \\
\text { (THB) }\end{array}$ \\
\hline SHS & & & & \\
\hline Initial Outlay & $\begin{array}{l}\text { Purchase } \\
\& \\
\text { Instal }\end{array}$ & 0 & 71,500 & 71,500 \\
\hline $\begin{array}{l}\text { Replacement } \\
\text { Costs }\end{array}$ & Controller & 10 & 4,569 & 2,805 \\
\hline & Inverter & 10 & 13,439 & 8,250 \\
\hline & Battery & 2 & 9,548 & 8,660 \\
\hline & Battery & 4 & 10,130 & 8,334 \\
\hline & Battery & 6 & 10,746 & 8,019 \\
\hline & Battery & 8 & 11,401 & 7,717 \\
\hline & Battery & 10 & 12,095 & 7,425 \\
\hline & Battery & 12 & 12,832 & 7,145 \\
\hline & Battery & 14 & 13,613 & 6,876 \\
\hline & Battery & 16 & 14,442 & 6,616 \\
\hline & Battery & 18 & 15,322 & 6,367 \\
\hline Total LCC & & & & 149,715 \\
\hline $\begin{array}{l}\text { Grid } \\
\text { Connection }\end{array}$ & & & & \\
\hline Initial Outlay & Instal & 0 & $3,250,000$ & $3,250,000$ \\
\hline Total LCC & & & & $3,250,000$ \\
\hline
\end{tabular}

Table VII indicates that SHS is superior in terms of $L C C$, making it inevitable to conclude that photovoltaic systems present a much more sound alternative for rural electrification in Thailand.

In Table VII, annual maintenance costs are not drawn into the $L C C$ analysis, yet they are in the order of $5 \%$ for SHS [4] and $15 \%$ for grid connection [6] of the initial outlay respectively. If taken into account, this further strengthens the case for the adoption of SHS in rural Thailand. 


\section{Conclusion}

The recent energy policies of Thai governments have aimed at providing $100 \%$ electrification in Thailand, reaching into remotest rural villages. The policy ought to be applauded since it seeks to improve the quality of life for remote villagers by applying benign contemporary technology. Of the two practically feasible options, adoption of photovoltaic technology to devise standalone solar home systems (SHS) strikes one as being much more pragmatic and attractive than connecting the remote villages to the national electricity grid. Implementation of SHS technology provides immediate benefits to rural villagers - albeit on a modest scale! Furthermore SHS technology is mature and its economic advantages seem to be indisputable in the present case.

\section{References}

[1] Jivacate, C. and Buakhiew, C., 'Photovoltaic (PV): status \& future development in Thailand', Proceedings of the $3^{\text {rd }}$ World Conference on Photovoltaic Energy Conversion, May 2003, pp. 2553-2555.

[2] Foley, G., Photovoltaic applications in rural areas of the developing world, The International Bank for Reconstruction and Development/World Bank Technical Paper Number 304, Washington D.C., USA, 1995.

[3] CIA - The World Fact Book - Thailand, https://www.cia.gov/cia/publications/factbook/geos/th.html (last viewed 20 January 2007).

[4] Prapasphen, S., Department of Alternative Energy Development and Efficiency (DEDE), Thailand (personal interview October 2004).
[5] National Statistical Office, viewed 15 Sep 2004 http://www.nso.go.th/thai/indext.htm.

[6] Akararungruangkul, S., Provincial Electricity Authority (PEA): Region 2 (Ubon), Thailand (personal interview November 2004).

[7] Hiranvarodom, S., Hill, R. and O’Keefe, P., 'A strategic model for PV dissemination in Thailand', Progress in Photovoltaics: Research and Applications, vol. 7, no.5, 1999, pp. 409-419.

[8] Solar Energy Map, Department of Alternative Energy Development and Efficiency, Thailand, http://www.dede.go.th/dede/index.php?id=665 (last viewed 20 January 2007).

[9] Messenger, R. A. and Ventre, J., Photovoltaic systems engineering, CRC Press LLC, USA, 2004.

[10] A Zahedi, The engineering and economics of solar photovoltaic energy systems, The New World Publishing, Melbourne, Australia, 2004.

[11] Solartron Co., Ltd., Solar modules, http://www.solartron.co.th (last viewed 20 January 2007).

[12] Leo Electronics Co., Ltd., Solarcon SE-T series, http://www.leonics.co.th/support/brochure/2_set_en.pdf (last viewed 20 January 2007).

[13] Leo Electronics Co., Ltd., Apollo S-100 Series Stand Alone Inverter, http://www.leonics.com/support/brochure/2_s100.pdf (last viewed 20 January 2007).

[14] Hankins, M., Solar electric systems for Africa: a guide for planning and installing solar electric lighting systems in rural Africa, Commonwealth Science Council \& AGROTEC, United Kingdom \& Zimbabwe, 1995.

[15] Solarcon BD-Series Deep Cycle Battery, http://www.leonics.com/support/brochure/2_bd.pdf (last viewed 20 January 2007).

[16] JA White, KE Case, DB Pratt \& MH Agee, Principles of engineering economic analysis, $4^{\text {th }}$ ed., John Wiley and Sons, New York, 1998. 